\title{
Moral Aspects of Some Combat Sports
}

\author{
Moralne aspekty niektórych sportów walki
}

\author{
Jacek Meller \\ Institute of Philosophy, Cardinal Stefan Wyszyński University in Warsaw, Poland \\ ORCID: https://orcid.org/0000-0002-0468-0168•j.meller@uksw.edu.pl \\ Received: 25 Jul 2020; Revised: 20 Aug 2020; Accepted: 24 Aug 2020
}

\begin{abstract}
Nowadays, sport is very popular as a way of spending free time, taking care of one's health and physical condition, as well as being an entertainment worth watching; sport is also judged positively, when it comes to moral aspects. However, there are disciplines that may cause doubts, because of the possible risk for the contestants (e.g. extreme sports), especially combat sports. The purpose of this article is to present an ethical analysis of full-contact combat disciplines. Their history shows a process of gradual brutalisation, in antiquity from battles during the Greek Olympics, to competitions in Roman arenas; in the modern age from regulations introduced in the $19^{\text {th }}$ century and the beginning of the $20^{\text {th }}$ century, to formation or restoration of combat, where almost no rules exist. Rules that apply in modern combat sports, lead to aggressive behaviour towards rivals, and give an advantage to the person who, not only strikes more technically correct blows or uses grips, but also reduces the opponent's ability to fight further. It leads to serious injuries whose consequences remain until the end of a contestant's life and make him a disabled person as time passes. Aggression that seriously harms a contestant, makes it impossible to morally excuse those sports.
\end{abstract}

Keywords: philosophy of sport, ethics of sport, combat sports, boxing, mixed marital arts

Streszczenie: We współczesnym świecie sport cieszy się popularnością jako forma spędzania wolnego czasu, dbania o zdrowie i kondycję oraz widowisko będące godziwą rozrywką; jest też oceniany pozytywnie pod względem moralnym. Pewne wątpliwości budzą jednak dyscypliny niosące większe ryzyko dla uczestników zawodów (sporty ekstremalne), zwłaszcza zaś sporty walki. Celem artykułu jest etyczna analiza dyscyplin walki pełnokontaktowej. Ich historia pokazuje proces stopniowej brutalizacji, w starożytności od walki podczas greckich igrzysk po zmagania na rzymskich arenach; w nowożytności od regulacji wprowadzanych w XIX i na początku XX w. po powstawanie lub przywracanie walk, w których reguł niemal nie ma. Zasady, które obowiązują we współczesnych sportach walki kierują do agresywnego zachowania wobec rywala i dają przewagę temu, który nie tylko zadaje więcej technicznie poprawnych ciosów czy stosuje chwytów, ale przez to realnie zmniejsza zdolność przeciwnika do dalszej walki. Prowadzi to do poważnych kontuzji, których skutki trwają do końca życia zawodnika czyniąc go z postępem czasu osobą niepełnosprawną. Agresja czyniąca poważną szkodę zawodnikowi sprawia, że sportów tych nie można moralnie usprawiedliwić.

Słowa kluczowe: filozofia sportu, etyka sportu, sporty walki, boks, mieszane sztuki walki 


\section{Introduction}

Sport as a spectacle that arouses great emotions became an important element of mass culture in the last half-century. Sport events attract millions of viewers - locally, in the stands, as well as globally, via media. The number of active participants of events that are intended for contestants in different age and on different levels is growing as well.

Even though there are many problems of moral nature connected with the increasing participation of sport in social life, especially with professionalization of this area of activity and far-reaching commercialization, fundamentally sport activity is judged positive. It serves the integral development of a person: his/her health, virtues formation, making correct social relations or integration of marginalized people and groups.

There is one exception from the fundamentally positive moral judgement of sport, especially cultivated as an amateur, and those are the so-called combat sports. Especially those combat sports, where a person gains an advantage over the opponent (referee points or a win before the passage of regular time of the duel) by striking blows - using only hands or all of limbs - as well as by mixing blows and grips. Examples of this are box, lethwei (Burmese box), muay thai (Thai box), kick-boxing, taekwondo and also ju-jitsu, mixed matrial arts (MMA) or pankration. Those disciplines, especially from mixed arts group, are becoming more and more popular: huge sports halls are full with fans and television transmissions attract many viewers who are ready to pay extra (aside from a regular subscription) for watching particular contests. Because of that, the interest of sponsors is increasing which leads to contracting high salaries to players, especially those who place on the highest positions in a particular federation.

The aim of this article is to analyse the moral aspect of combat sports. The focus will be on boxing (in amateur and professional versions) and mixed boxing martial arts (mixed marital arts, MMA) - due to their greatest popularity and representativeness for all the abovementioned disciplines. Strictly ethical considerations will be preceded by the presentation of the history and principles of these sports, which will allow to extract their essence.

\section{History}

It is difficult to find a moment in history, in which martial art became a sport discipline. Perhaps, it was connected with a necessity of keeping combat readiness or efficiency in hunting - that is, systematic exercises, which in combination with the evolutionally conditioned propensity to compete, resulted in fighting training: with real effort and the possibility of indicating the winner, but not leading to death or more serious injury to participants.

Testimonies of the existence of boxing fights in antiquity in the Middle East, bring Babylonian and Egyptian finds: painted plates and paintings in the derived tombs from the $5^{\text {th }}$ and $6^{\text {th }}$ millennium B.C., depicting first of all struggling boxers (The British Museum 2020; Tour Egypt 2020). Egyptian images evidence the ludic character the nature of the presented scenes; in both cases, however, the rules of the duel are unknown nor the circumstances of this holding. Custom of fistfights in the Far East are confirmed by published in the middle of the $3^{\text {rd }}$ millennium BCE. in China, the rules of "art reason."

More information about boxing and also pankration, that is a mix of boxing and wrestling, archetype of modern MMA, include written sources from Greece. In "Iliad" Homer described a competition that was a part of Patroclos' funeral ceremonies; this competition included, first of all, cart race and run, fistfight and wrestling, archery and a duel with spears and swords. The fight was brutal, and it could lead even to the death of the contestant: Epejos, one of the contestants, threatens to "crush body and break bones" of the rival (Homer 1981, song XXIII). Fighting during the time of the Olympics organised at Olympia was not different. 
Boxing was introduced to the competition program in 688. BCE, and the rules were not complicated: it was allowed to hit the head and shoulders of the opponent, the duel continued without interruption until one of the rivals gave up or became unable to continue the fight; the division into weight categories was not known. For greater effect of the blows and to protect hands, players wrapped them with straps. A tie was not considered; if after a long time the players weakened and the winner could not be selected, a procedure was carried out somewhat similar to a penalty shootout: boxers struck each other after one blow, however, unable to defend themselves. Forty years after boxing, pankration was included to the program of the Olympics - hand-to-hand combat in which only biting was prohibited, as well as attack on the eyes. Just like in boxing, the duel continued without interruptions until complete exhaustion of the rival; deaths in the ring were not infrequent in both competitions. The Romans took over boxing from Greek culture; introducing some changes over time: the players were less likely to die on a ring (because the death of a boxer-slave meant the end of gaining income by his master), duel ended with a knockout or surrender. On the other hand, metal pieces that severely injured the rival were attached to the straps protecting the players' hands. At the National Museum in Rome, there is a stored, well-preserved bronze sculpture of the "Boxer of Quirinale" with thick leather straps on the hands with visible metal reinforcements (Arte e cultura 2020; Karpiński 2015; Rodriguez 2009, 23-24).

With the suppression of the Games in 393, the history of ancient boxing ended. During the period of the Middle Ages and the first part of the modern era fist fighting was not an element of entertainment of the upper classes. However, it was practiced as a fight of individuals or whole groups (e.g. inhabitants of different villages) during folk games or periodical rituals.

Boxing came back as a sport discipline in the first half of the $18^{\text {th }}$ century in England. It happened thanks to James Figg, later called "the father of boxing", who transformed a fist fight from brutal violence to an equivalent of fencing requiring not only physical effort, but also mind effort. From the mid of $18^{\text {th }}$ century ("London Prize Rules") to the end of the $19^{\text {th }}$ century regulations regarding the battlefield, required gloves, time of the match, weight classes or counting a downed competitor up to 10 seconds were formed. As in the case of other sports, clubs and their federations organizing regular competitions were created. Boxing went to the United States along with British migrants - and it was between the British and Americans that the first international duel was played at the beginning of the $19^{\text {th }}$ century. Boxing was not equally popular everywhere, it was even, like in Sweden, prohibited. It was introduced to the set of Olympic disciplines thanks to Americans (1904 Games in St. Louis).

Nowadays, boxing is very popular and is developing in two main trends: amateur and professional (both in male and female version). As the names indicate, they differ from each other in administrative matters (the method of financing players and competitions, other weight and age categories), but also in certain rules of fighting.

The change introduced in amateur boxing in 2013 is worth mentioning here. From the beginning of the 1980 s, players were required to use protective helmets, now this equipment is prohibited. This change is characteristic of the whole history of boxing. There are voices that speak about "gladiatorization" of this discipline, about such changes that make the competition more spectacular, attract bigger and bigger audience looking for strong emotions, but at the cost of exposing the competitors to serious bodily injuries, often long-term effects and even death. Competitions in disciplines that are a speciality of small national or regional groups are also regionally watched: lethwei (Burmese boxing), muay tai (Thai boxing), kick-boxing, taekwondo or ju-jitsu. Mixed martial arts have gained enormous popularity in recent 
years, and fights without the use of gloves are also prepared, which is more prone to injury to the hit and striking (Lewicki 2020). You can get the impression that a globalized free market with the audience, media, promoters, and competition organizers would gladly bring back fights of gladiators ready to die for fame and money.

\section{Fighting rules}

Rules' analysis of federation of amateur boxing (AIBA) and professional boxing (WBC or WBO) allow to state that the rules of the fight do not differ meaningfully. It can be seen, for example, in the catalogue of prohibited behaviour on the ring of every organisation: it is prohibited to kick, bite, spit, hold, push, pull, attack lying person, hit with head, elbow, arm, open glove or wrist, hit below the belt, in the back of the head and back. Scoring system was also unified, helmets are not used during any senior competitions nowadays.

Fights of professionals and amateurs differ in duration time (accordingly 12 and 3 threeminute rounds). Important difference is a possibility of "enumeration up till eight" of contestant, who after a strong hit did not fall, but for a moment lost the ability of taking up the fight (knock-down). This procedure cannot be carried out on a professional ring (International Boxing Association 2019, World Boxing Organisation 2020, World Boxing Council 2020).

In amateur boxing, the basic way of winning is performing as many strikes, in accordance with the regulations, as possible towards the opponent. Those strikes are counted, rated and scored by referees (WP). There is a possibility of surrender of the opponent, surrender him by his second (ABD), acknowledging the contestant as unable to further fight by the referee (RSC, RSC-I) and disqualification (DSQ). The last mentioned is knock-out (KO), which means striking such a strong blow to make the contestant unable to continue the fight for $10 \mathrm{sec}-$ onds. In professional boxing the order is reversed: the basic way to choose a winner is knock-out; if it does not occur, referees score all the rounds. Rules include also the remaining possibilities (International Boxing Associations 2019, World Boxing Organisation 2020, World Boxing Council 2020).

A different order - if it has an assigned meaning - makes amateur boxing a technical discipline, where the contestant's task is to show the skill of avoiding the rival's blows and strike correct blows, but not necessarily ones making him unable to continue the fight. The kind of used gloves also indicates that: amateur gloves make it harder to do a knock-out because of their construction and weight, professional gloves make the knockout easier.

The rules regarding breaks between fights are also important. Amateurs take part in tournaments lasting several days, fight a few duels during a short time; rules in professional boxing impose a few weeks' (or a longer) break between fights. In this context, professional boxing would definitely be seen as a strength discipline that brings down the contestant's goal to eliminating the rival with even one, properly struck blow. As it may seem, this difference in practice does not mean anything; amateurs also aim at the quickest elimination of the rival and in sports' records of winning duels always bring to the fore those who ended before the regular time. Both in professional boxing and amateur one, contestants try to strike the opponent those kinds of blows that will make him unable to continue the fight.

\section{Injuries and contusions}

Paraphrasing a well-known saying, one may conclude that "only the one who does not do sports, does not get injured". Indeed, aboveaverage physical activity leads to different damages of body parts used in particular discipline, but also different systems disturbances (e.g. that of the circulatory or the nervous system). Medical problems might be connected with single events during sports practise but also with long lasting loads of parts or body systems. Sport researchers point out disciplines that may 
cause injuries to a greater or smaller extent. It is connected with the nature of activities (getting speed, being at height) and with a direct interaction with the opponent. The player, either professional or amateur, must take into consideration the possibility of health damage, which sometimes excludes him or her from doing a particular discipline, as well as other types of activities, for a longer period of time.

Injuries in sport may have very different causes. The possibility of injury may increase because of external factors towards the contestant: mistakes in conducting classes, insufficient technical security, lack in organisation or unfavourable conditions. Behaviour of a sportsman, his inadequate preparation, tiredness, and effects of previous injuries, overstrain and functional changes in his body may contribute to the increasing number of unwanted events during training and contests. In most disciplines, the first place among the causes of injuries befalls the behaviour of contestants and methodical mistakes in conducting classes - it is not different in boxing. The cause of over 30\% injuries in general, and over $60 \%$ injuries that happened during the fight, was the behaviour of the contestant. Lack of technical security causes around $25 \%$ of boxers' injuries, incorrect methodology of conducting classes causes about $19 \%$. Taking also into consideration that accidents happen more often to less advanced sportsmen, one may point out basic directions of working on decreasing number of injuries: constant improvement of training contestants, trainers and other members of preparation team, as well as referees who control the course of the competition.

During a fist fight, the contestants from both sides of boxer's gloves are exposed to injury, however the striking one is in a much better position. He is, of course, exposed to hand injuries, especially that of the thumb and metacarpal bone and wrist as well as, to a lesser extent, to injuries of muscles, tendons and joints around arm and shoulder belt, but such injuries do not involve any threat to life and do not have such unfavourable long-term effects as those risked by the contestant who is being struck. It is worth mentioning that the equipment used by contestants: gloves, bands and bandages protects mostly the one who strikes a blow. His opponent is exposed firstly to skin abrasions, suggillations (colloquially called "bruises") and also breaking the skin on the brow bone or the zygomatic arch. Although they are not qualified as severe injuries, profuse bleeding from a brow bone may prevent the contestant from further fight. Characteristic of boxers and other martial arts fighters is the so called "cauliflower ear" - a distortion of the ear lobe caused by one major or many smaller injuries of the cartilage that builds this organ. Broken bones are more serious injuries; boxers are exposed to the injury of the jawbone, other bones of the facial skeleton, or, less frequently, ribs or forearms. Spine fracture may occur as a result of falling out of the ring and falling from its height. Also, the boxer's internal organs are exposed - especially the ones on the abdominal side of the torso - the liver, spleen, pancreas and stomach. Because punching in the back is forbidden, kidneys are relatively seldom injured; the contestant who attacks this way may be disqualified.

The most important for the contestant's safety are blows inflicted in the area of the heart and the head. The first one may cause cardiac standstill (by ventricular fibrillation), which is a condition that may threaten life directly. The second, brings immediate and short-lasting effects, like temporary balance disability and shortterm loss of consciousness or concussion. Those conditions are the cause of ending the fight before time (KO). Blows repeated many times, not even so strong as to lead to a knock-out, bring long-term effects, connected with cumulative microdamage of the nervous tissue. Over time, symptoms of traumatic encephalopathy, sometimes called "boxer dementia", occur and increase. Its symptoms in the physical sphere are 
stiffness and slowing down movements and speech; in the psychic sphere they include lack of emotional balance with aggression episodes, troubles with memory and slowing down of the thought process. Disturbances of consciousness, problems with motor coordination which unable a person to do basic activities, parkinsonism, will occur in the most advanced phase (PtaszyńskaSarosiek et al. 2010, 173).

In the description, quantitative and comparative statistics were omitted on purpose: how many and what kind of injuries, accidents happen to contestants of different disciplines. The reason of that is not only complication of those comparisons where the popularity of particular discipline, number of contests, time spent of trainings, etc. must be included. The important part is not the fact of getting injuries itself, not even life threat but a particular regularity.

It is emphasized that an injury, even if allowed, is beyond the intention of a sportsman; it is something unwanted and accidental. A contestant, who causes an injury of the opponent by behaving against the rules, is punished - even with disqualification. Rules, actions of organisers and referees during contests, and also the behaviour of contestants should protect themselves and their rivals from injuries; young adepts are taught methods of preventing injuries, there are also actions taken for the equipment not to cause danger.

Overview of boxer fights' rules imply that in the box, especially a professional one, and also among other combat sports, the aim is to eliminate the opponent, make him unable to continue the fight. It is not like, for example, in wrestling, where the defeated contestant (knocked-out or immobile) can still fight, but is forbidden by the contest rules; the rules of the boxing duel (also MMA, karate, kyokushin, muay thai...) lead to physical elimination of the rival, making him unable to fight even if he wanted ${ }^{1}$. It may hap-

1 A good illustration here might be an instructional video with a "throw at the head" in MMA. pen by one knock-out, short suspension of combat capability three times in one round (only in amateur boxing, the referee counts the contestant up to eight) or causing a contusion, which is not connected with loss of consciousness, but makes further duel impossible or too dangerous for the contestant. It is important to emphasize that this situation cannot be changed by regulations of amateur box, which in the first place links a victory with points advantage: knock-out is rewarded with a victory before the end of the regular time, in boxer's biography those victories are pointed out separately as an important element of his life achievement which makes them a desired aim.

\section{Aggression}

There are many motives of people's interest in sports activity and they all grasp the essence of it. According to the ludic conception this essence means selfless fun, according to the perfectionist conception it means fulfilling aspiration of individuals and societies for perfection (not only as regards body efficiency but also mental faculties, ability to undertake regular effort, perseverance, teamwork skills and copying with failure), and even spiritual faculties, e.g. holiness. Educational interpretation is close to the second conception: sport is a tool of shaping a man, especially a young one, develop in him features that are desired in society. In the context of combat sports agonistic interpretation should be distinguished. According to it, the essence of sport is to fight: with time and space, with the opposed forces of nature, with one's own weakness, and also with a particular personal opponent, who has to be defeated by a stronger, faster, more efficient and resilient person... However, it is a special fight, different from the one taking place during war. Its purpose is not to physically eliminate the opponent or deprive him of

After doing a throw by which he knocks down the opponent, the instructor inflicts fake blows to the lying person (https://www.youtube.com/ watch?v=wtKfbH_fa5k). 
access to goods important for life, but only to prove one's superiority in a particular field (Judycki 2019; Stryczek 2011, 58-60; Kowalczyk 2010, 24-31). Transformation of such a destructive action into sport takes place thanks to creating and following the rules, which protect players and prevent them from getting hurt in ways other than depriving them of victory and the connected benefits (if it may be qualified as getting hurt). The unwritten and hard to specify "fair play rule" is also important; it not only requires following current game rules but also speaks to honour which for example will not allow to use a coincident unfavourable for the opponent (Kosiewicz 2003, 326; Stryczek 2011, 123-136).

It is worth mentioning that sport arenas were and still are considered as a substitute for a real fight between countries or political blocks. The clearest example here is perhaps the rivalry of sportsmen from opposite sides of "the iron curtain" lead and supported by state authorities. On the other hand, sports events may be a spark that ignites smoldering conflicts (as it was with the socalled "football war" between Honduras and Salvador in 1969) or become a background for acts of violence towards the "different ones" - from different district, religion or social group, whose sign is supposed to be a scarf in colours of other team (Ostleroff 1976, 260; Lipiec 2007, 171).

Not judging the rightness of the agonistic concept in sport interpretation - all of the concepts mentioned here are slightly one sided and do not explain the whole phenomenon - it should be realised that in media coverage aspect of fight, advantage, defeating the opponent are often in the centre. Sportsmen who "fight" are not only people who do judo or fencing, but also representatives of non-contact disciplines like volleyball or pole vault. The competitor is "defeated", sometimes "with a crushing advantage", bar hanging on a particular height (or the height itself) should be "attacked"; similarly all of the attempt to gain advantage, even faster run or cycling may be called "an attack".

The word "aggression" occurs very often in reports of sports events, and it is not only in live ones which involve stronger emotions. Such expressions as "sport aggression" (or sport anger), "aggressive defence" or speaking about aggressive ride of a driver or cyclist, and finally, directly about aggressive contestants of different disciplines are very frequent. The word "aggression" replaces "risky behaviour", "activeness", "readiness to maximum effort", "intransigence". This way aggression gains a positive meaning, it is included among those qualities of the sportsman and his activity which bring him success (Kalina 2007, 158-160; Żukowski 2007, 231). Language is a living reality, changing in a way difficult to control and lead, it is not known, if a presented phenomenon will be strengthened. One may wonder about the presence of aggression (in traditional understanding) in sport. Subject of this thought will be sport in the strict sense, especially considered here combat sports, without serious problems connected with aggression around sport: societies of socalled "pseudo-fans" or criminality growing around sport.

Online Polish language dictionary PWN defines aggression as: "hostile, offensive behaviour; also: strong negative emotions causing this behaviour" or "armed attack of one country on another" (Słownik Języka Polskiego PWN 2020). Other terms complement this word with the meaning implying the intention of harming somebody or causing him injury, thus emphasizing the essence of aggression: it is directed to inflict pain, destroy, cause suffering. However, some authors single out two types of aggression: intended and instrumental. The first one is understood as a destroying power, directed to inflict evil to someone, sometimes without a clear reason; it is often accompanied by rapid emotions, it happens that the aggressor loses his temper and does actions which he later regrets, not even denying the rightness of aggression itself in 
a particular situation. The second type of aggression is devoid of the implied intention of harming as mentioned above. The subject, by showing behaviours that look aggressive (malicious), wants to achieve a defined goal, not harming other people at the same time and not directing actions against them (Kłodecka-Różalska 2007, 90-91; Zdebska 2007, 99).

This nature of behaviour would be seen in majority of sportsmen, who take a ball from each other on arenas, push each other in a crowd of runners and even do a "tactical foul". Those acts are not intended to cause suffering, not aimed at the opponent himself; they are necessary means to achieve a goal which is a sports victory. Majority of those acts are included in regulations, they are indeed harmless acts, which can be used by all competitors. A "tactical foul" looks slightly different, it is an irregular behaviour displayed with premeditation in the face of inability to stop the contestant in another way. Most fouls in its nature, may lead to injuries (and that is exactly why, being dangerous behaviours, they are called fouls). So, committing a foul must at least assume acceptance for potential harm done to the opponent. This way, it does not fit into the term "instrumental aggression", it becomes an act of aggression intended towards someone who stands on the way to achieving a victory. It is hard for the spectator or commentator of a contest to look into sportsmen' hearts and minds, however, it is known from particular comments that an authentic hostility towards the rival in a game may occur, a hostility that is a part of motivation which anew awakens strength for action. This hostility may be fuelled by coaches, activists, or fans. "I imagined myself shooting at enemies. Before we left, my Great Leader Kim Il-sung told us to shoot as if we were fighting our enemies. That's exactly what I did do" said Li Ho-jun, an Olympic champion in shooting from small calibre carbine in Munich in 1972 (Kalina 2007, 162; Żukowska 2007, 216; Witt 2012, 166; Cynarski and Kuśnierz 2017, 119).
What happens on the mat, in the cage or in the ring seems to be the embodiment of aggression, almost - taking into consideration the setting of professional fights - its feast. It should be considered, whether we deal with aggression in its right understanding, as it was called above, the "intended" aggression or whether it is just an appearance of it, i.e. instrumental aggression. This instrumentalism would mean that contestants who punch, kick, pull, throw the opponent do this only incidentally, not having any intentions in harming the other contestant, do it only to show their superiority over the opponent and get the winner's laurel.

The one who knows, however, how fullcontact combat arts work, understands that this thesis cannot be defended. Contestants are rewarded for striking real blows, which entails natural effects, even life threat. Special quality of victory before time, especially by $\mathrm{KO}$, means that the stronger the push is the more valuable it gets from the perspective of the person who struck it. So, there is no pretending here, such a sports fight is in fact an expression of brutal strength leading to depriving the rival the ability to continue the fight. It is difficult, sometimes, to see through the intentions of contestants; during press conferences or interviews they repeat the cliched comments and opinions learned by heart. If words do not reflect the essence of events, the intention of the speaker should be considered when it comes to its authenticity or a situation of internal hypocrisy or dichotomisation.

In combat sports there is, however, a particular boundary concerning aggressive behaviours - it is set by rules of a specific discipline. Rules do not regulate the inner attitude of the contestant, his intentions or hierarchy of values; rules show only what is permitted and what is not on the mat or in the ring. One may ask about the source of this regulation, perhaps people who are responsible for its establishment will show concern about the health and life of 
contestants. There is one open question, why in one discipline those goods are taken care of better (by for example by forbidding hitting a lying person) and in others rather neglected (permitting hitting, but not kicking). Organizers and promoters of disciplines and individual contests do not conceal that rules of fights are made to make a show of it, because it increases the number of spectators in sports halls and in front of the television, and so the income earned by stakeholders (Żukowski 2007, 231; Kosiewicz 2007, 283). This motive lied behind, among other things, lifting the obligation that was in force since the 80 s, to use protective helmets by amateur boxers. Contestants' activity, readiness to increased effort, leading risky actions and spectacular victories - this is something that people who go for "galas" or pay for the possibility to watch transmission want to watch. "We miss nature, miss wildness, world of gladiators and great warriors" - writes one of commentators about plans to introduce bear fists fights (Lewicki 2020). And perhaps no one will complain that instead of contracted ten rounds, he watched only five, if the fight ended with knock-out after one of the contestant's reckless attack. Conclusion that rules limit aggression in combat sports is at least partly untrue.

\section{An attempt at ethical evaluation}

Sport, especially amateur sport, that is not focused on breaking high records and not commercialized, has a positive moral judgement as a means of caring for body health and good mental condition, as well as a method of personality shaping. The trainee develops, not only strength, flexibility and endurance, but also perseverance, patience, moderation, the ability to fail and - especially in team disciplines - the ability to cooperate in a group. It is important that sport activity is based on the correct understanding of a human being as a free and rational, physical and spiritual being at the same time, without exaggerating the cult of body, youth, health or strength on the one hand and without humiliating, purely instrumental treatment of what is material in a human being on the other hand (Stryczek 2011, 78-82).

The moral problems of sport are also noticeable, especially in the case of professional, high-performance sports. Commercialization, striving for victory at all costs through the use of excessive loads or unfair doping, the high risk in extreme sports - there are only few aspects of modern athletic, which need to be taken into consideration when making an attempt of ethical rating of a discipline or sport event.

The field of full-contact combat sports also struggles with the above-mentioned problems, but in this moral assessment they do not seem to be the most important. The nature of actions relevant for practising those disciplines wakes concerns. According to rules regulating boxing, especially professional, karate kyokushin, pankration or mixed martial arts, the aim of contestants is to deprive the rival of the ability to fight, but not symbolic, through throwing him on the ground or immobilize like in wrestling or touching the swordsman's vest with the blade with an inbuilt electrical circuit. The elimination is real: the contestant loses consciousness or is injured in a way making him unable to fight anymore. In this situation, in the field of an ancient or medieval battle he would get killed or taken captive, and his command would have to note down "loss in people".

Fight leads to the infringement of bodily integrity of the contestant, and to harm. It is clearly showed by presentation of health consequences of taking part in competitions. Broken bones, damage to internal organs, mental impairment, even direct life threat - those are aims, to which action of the contestant who enters the ring leads (Murzyn 2018).

That is why, from the point of view of either absolute ethics or consequentialist ethics, taking part in a fight cannot be justified. Harming an innocent person, even if this person agrees to that by accepting 
sports challenge, has signs of a deed which is intrinsically wrong. It seems that the calculation of effects is also disadvantageous: serious health consequences strains not only losers, but also winners, who enjoy a big income and fame, but at the price of serious health damage. Muhammad Ali, who won 56 of 61 fights in a professional ring (more than a half by KO), suffered from Parkinson disease since he was 42 , the disease was an effect of boxing profession. "Professionals let themselves getting hurt for money" - was said during the interview with kickboxing coach (Polish Kickboxing Association 2020).

The attempt of moral defence of combat sports may perhaps apply only to amateur boxing and with some reservation. Supporters of this discipline point out that the aim of the contestant is to gain points for blows, regardless of their strength; it is not the aim of a duel to cause any injuries (O'Halloran 2020; Polish Kickboxing Association 2020). According to this, however, the boxer is supposed to be punished and not rewarded with a victory before time, for causing the opponent's injury, the opponent should be protected from injuries much better. Meanwhile, $\mathrm{KO}$ is a victory more appreciated than a victory for points, and various protection means (excluding gloves) are used only by very young contestants now.

\section{Conclusion}

Martial arts have a long history dating back to the beginnings of human civilization and today enjoy an unwavering popularity. This is the cause of huge media interest and sponsors looking for ways of promoting themselves.

Although doing a sport, especially an amateur sport, is morally right, the principles and practise of martial arts, especially in the professional and fullcontact form, raise serious moral concerns. They are connected with the essence of combat sports: they are an activity aimed at harming the rival. Negative consequences of practicing martial arts are partially limited by the fighting rules. The contestant's activity seems to be a manifestation of intended aggression towards the rival. It needs to be highlighted that growing commercialization, especially involvement of sponsors and mass-media favors brutalization of combat sports. The discipline based on harming stops being a sport, it becomes a space of violence and harm; space that should be as limited as possible.

The thought that it would be possible to introduce a ban on full-contact fighting seems utopian (although in liberal Norway and the regime in Cuba and North Korea such bans are in force), but actions on two levels are necessary and possible. On the one hand, regulations should be created to protect contestants, especially the young ones, in the best way; on the other hand communities should be formed, through educational and journalistic activity, in a way where things that look like barbarianism hidden under the mask of sport become less and less popular.

\section{Bibliography}

Arte e cultura. „Bokser z Kwirynału/Pugile in riposo [Boxer from Quirinal Hill/Pugile in riposo]." Accessed May 10, 2020. https:// arteculturaitalopolacca.com/2018/03/05/ bokser-z-kwirynalu-pugile-in-riposo/.

Cynarski, Wojciech, and Cezary Kuśnierz. 2017. „Wpływ sztuk walki na osobowość osób trenujących." W Kultura fizyczna a osobowość, red. Zbigniew Dziubiński and Krzysztof Jankowski, 113-121. Warszawa: Akademia Wychowania Fizycznego w Warszawie.

Homer. 1981. Iliada. Wrocław: Zakład Narodowy im. Ossolińskich.

International Boxing Association. 2019. AIBA Technical \& Competition Rules. Access May 30, 2020. https://d21c25674tgiqk.cloudfront. net/2019/03/AIBA-Technical-Competition-Rules-. pdf.

Judycki, Stanisław. 2020. Filozofia sportu. Access October 15, 2019. http://www.kul.edu.pl/files/57/ wydzial/judycki/filozofia_sportu.pdf.

Kalina, Roman. 2007. „O odpowiedzialnym używaniu pojęć «agresja» $\mathrm{i}$ «agresywność» w opisywaniu 
walki sportowej - czy kwestia niekompetencji semantycznych?" W Sport a agresja, red. Zbigniew Dziubiński, 157-165. Warszawa: Akademia Wychowania Fizycznego w Warszawie.

Karpiński, Dariusz. 2015. Elementarz boksu. Głogów: Fundacja My Wojownicy.

Kłodecka-Różalska, Jadwiga. 2007. „Zachowania agresywne w sporcie: dominacja nadziei i optymizmu nad pesymizmem i zwątpieniem." W Sport a agresja, red. Zbigniew Dziubiński, 9098. Warszawa: Akademia Wychowania Fizycznego w Warszawie.

Kosiewicz, Jerzy. 2003. „Zasada fair play a wartości sportu." W Spoteczny wymiar sportu, red. Zbigniew Dziubiński, 323-329. Warszawa: Akademia Wychowania Fizycznego w Warszawie.

Kosiewicz, Jerzy. 2007. „Rozważania o agresji w sporcie." W Sport a agresja, red. Zbigniew Dziubiński, 281-290. Warszawa: Akademia Wychowania Fizycznego w Warszawie.

Kowalczyk, Stanisław. 2010. Elementy filozofii i teologii sportu. Lublin: Wydawnictwo KUL.

Lewicki, Adam. 2020. „Historia zatacza koło, a ludzie chcą igrzysk. Czy walki na gołe pięści są bezpieczne?" Access June 10, 2020. https:// sport.onet.pl/boks/gromda-walki-na-gole-piesciczy-sa-bezpieczne-mateusz-borek-beda-emocje/ e3tmsdy.

Lipiec, Józef. 2007. „Sport zamiast wojny, czy wojna zamiast sportu?" W Sport a agresja, red. Zbigniew Dziubiński, 271-280. Warszawa: Akademia Wychowania Fizycznego w Warszawie.

Murzyn,Marcin.2018.„Czyistniejąsportyniemoralne?” Access May 12, 2020. https://kierunki.info.pl/ marcin-murzyn-czy-istnieja-sporty-niemoralne/. O’Halloran, Nathan. „Czy ksiądz może uprawiać boks?" Access May 15, 2020. https:// deon.pl/wiara/wiara-i-spoleczenstwo/ czy-ksiadz-moze-uprawiac-boks, 510273.

Ostleroff, Wiesław Konrad. 1976. Historia sportu. Warszawa: Nasza Księgarnia.

Ptaszyńska-Sarosiek, Iwona, Anna NiemcunowiczJanica, Marcin Filimoniuk, Zofia Wardaszka, Magdalena Okłota, Michał Szeremeta, and Adam Sackiewicz. 2010. „Cerebrastenia pourazowa i encefalopatia pourazowa - trudności opiniodawcze." Archiwum Medycyny Sadowej $i$ Kryminologii 40(2-3): 172-176.
Polski Związek Kickboxingu. 2020. „Wywiad z trenerem Tomaszem Skrzypkiem." Access May 15, 2020. http://www.pzkickboxing.pl/news/156,wywiad,trenerem,tomaszem,skrzypkiem.html.

Rodriguez, Robert G. 2009. The Regulation of Boxing. Jefferson: McFarland \& Company.

Słownik Języka Polskiego PWN. „Agresja.” Access June 10, 2020. https://sjp.pwn.pl/szukaj/agresja. html.

Stryczek, Maria. 2011. Aksjologia sportu. Lublin: Katolicki Uniwersytet Jana Pawła II.

The British Museum. „Plaque.” Access May 23, 2020. https://www.britishmuseum.org/collection/ object/W_1856-0903-1522.

Tour Egypt. „Ancient Egyptian Sports.” Access May 23, 2020. http://www.touregypt.net/ historicalessays/ancsportsg1.htm.

Witt, Richard. 2012. Lifetime of Training for Just Ten Seconds: Olympians in Their Own Words. London: A\&C Black.

World Boxing Council.2020."Rules For Championship Fights." Access May 30, 2020. https://wbcboxing .com/en/wbc/documentos/?\&cp_71=1.

World Boxing Organization. 2020. "Regulations Of World Championship Contests.” Access May 30, 2020. https://www.wboboxing.com/wp-content/ uploads/2020/02/WBO-Regulations-of-WorldChampionship-Contests21830.pdf.

Zdebska, Halina. 2007. „Sport a agresja.” W Sport a agresja, red. Zbigniew Dziubiński, 99-110. Warszawa: Akademia Wychowania Fizycznego w Warszawie.

Żukowska, Zofia. 2007. „Poczucie własnej wartości a zachowania agresywne w sporcie." Sport a agresja, red. Zbigniew Dziubiński, 211-218. Warszawa: Akademia Wychowania Fizycznego w Warszawie. Żukowski, Ryszard. 2007. „Trener a agresja w sporcie.” W Sport a agresja, red. Zbigniew Dziubiński, 227-233. Warszawa: Akademia Wychowania Fizycznego w Warszawie. 